\title{
Correction: Decade of action on nutrition: our window to act on the double burden of malnutrition
}

Demaio AR, Branca F. Decade of action on nutrition: our window to act on the double burden of malnutrition. BMJ Glob Health 2017;3:e000492. doi: 10.1136/ bmjgh-2017-000492.

This article was originally published in Volume 2, Issue 4 but has since been moved to Volume 3, Issue Supplement 1.

Open Access This is an open access article distributed under the terms of the Creative Commons AttributionNonCommercial IGO License (CC BY-NC 3.0 IGO), which permits use, distribution, and reproduction for non-commercial purposes in any medium, provided the original work is properly cited. In any reproduction of this article there should not be any suggestion that WHO or this article endorse any specific organization or products. The use of the WHO logo is not permitted. This notice should be preserved along with the articles original URL. See: https://creativecommons.org/licenses/ by-nc/3.0/igo

(C) World Health Organization [2018]. Licensee BMJ

BMJ Glob Health 2018;3:e000492corr1. doi:10.1136/bmjgh-2017-000492corr1

A Check for updates 